\title{
MEKANISME PASAR PRODUK USAHA KREATIF HOME INDUSTRI DI DESA BODELOR DALAM TEORI IBN KHALDUN
}

\author{
Abdul Aziz, Achmad Dasuki Aly dan Nila Afifah \\ Fakultas Syariah dan Ekonomi Islam \\ Institut Agama Islam Negeri Syekh Nurjati Cirebon \\ e-mail:razi_ratnaaziz@yahoo.co.id,abahali_sukses@yahoo.com \\ dannillaafifah@yahoo.com
}

\begin{abstract}
Bodelor Village is a creative product business center with several home industries with products such as mukenah, kerudung, rattan handicraft and bamboo blinds. Progress of Bodelor village in the product of this creative business needs a healthy market mechanism between home industry owners in competing. So in determining the price of a fair product is left to the market mechanism itself. To find out the existing market mechanism, the authors looked at it using Ibn Khaldun's theory of market mechanisms. The method used in this research is qualitative by using the theory of Ibn Khaldun as a reference. Techniques of data collection conducted, namely observation, interview and documentation. Based on the results of existing research related to the theory of Ibn Khaldun, in the market mechanism there are similarities in the process of price creation influenced by demand and supply, workers, government, money, taxes and security. Price increases also occur when demand and supply of goods are unbalanced. The difference lies in the decline in the price of a product.
\end{abstract}

Keywords: Creative Business Products, Home Industry, Ibn Khaldun Market Mechanism.

\begin{abstract}
Abstrak
Desa Bodelor merupakan sentral produk usaha kreatif yang memiliki beberapa home industri dengan produk berupa mukenah, kerudung, kerajinan rotan dan kerai bambu. Kemajuan desa Bodelor dalam produk usaha kreatifnya ini membutuhkan mekanisme pasar yang sehat antara pemilik industri rumahan dalam berkompetisi. Sehingga dalam menentukan harga sebuah produk yang adil diserahkan kepada mekanisme pasar itu sendiri. Untuk mengetahui mekanisme pasar yang ada, penulis melihatnya dengan menggunakan teori mekanisme pasar Ibn Khaldun. Metode yang digunakan dalam penelitian ini adalah kualitatif dengan menggunakan teori Ibn Khaldun sebagai referensi. Teknik pengumpulan data yang dilakukan, yaitu observasi, wawancara dan dokumentasi. Berdasarkan hasil penelitian yang ada terkait dengan teori Ibn Khaldun, di dalam mekanisme pasar terdapat kesamaan dalam proses terbentuknya harga yang dipengaruhi oleh permintaan dan penawaran, pekerja, pemerintah, uang, pajak dan keamanan. Kenaikan harga juga terjadi ketika permintaan dan penawaran barang tidak seimbang. Perbedaannya terletak pada penurunan harga suatu produk.
\end{abstract}

Kata Kunci: Produk Usaha Kreatif, Home Industri, Mekanisme Pasar Ibn Khaldun. 


\section{PENDAHULUAN}

Dalam perekonomian global ini di mana persaing sangat ketat dan memiliki kemampuan, serta kecepatan yang tinggi dalam memulai suatu usaha. Dengan memulai usaha kecil ini menjadi titik luncur bagi para wirausaha. Terdapat dua faktor utama yang melatarbelakangi pertumbuhan ekonomi dengan menjalankan bisnis usaha kecil ini karena kebebasan untuk menjalankan usaha sendiri dan memiliki banyak waktu bagi mereka. Biaya produksi yang rendah juga menjadi alasan lain untuk memulai bisnis berbasis rumah ini. ${ }^{1}$

Agar dapat bersaing dengan pengusaha lain, para pebisnis kecil memerlukan produk usaha yang kreatif. Sebuah bisnis bukan hanya bertujuan untuk keuntungan semata, namun harus mengedepankan juga imajinasi yang unik dan kreatif yang dibentuk dengan kreasi yang luar biasa.

Desa Bodelor sendiri merupakan sentral usaha kreatif. Desa ini terkenal dengan usaha kreartifnya dalam bentuk fashion seperti mukenah dan kerudung. Selain produk kreatif dalam bentuk fashion, terdapat juga seni kerajinan kreatif seperti kerajinan rotan dan kerai bambu. Ketika seorang pengusaha sudah mampu membuat sebuah produk, maka yang terpikir dalam benaknya adalah bagaimana dapat menjual produk yang telah dihasilkan agar tidak mengalami kegagalan ketika mengenalkan dan memasarkan produk yang baru mereka rilis di pasar. $^{2}$ Setelah itu, mereka harus mengevaluasi suatu produk yang sudah jadi apakah layak untuk dipasarkan atau tidak, jika sudah ditentukan kelayakannya, penerapan strategi penetapan harga yang baik oleh seorang pelaku usaha di dalam pemasarannya akan membawa hasil yang memuaskan bagi kedua belah pihak yang

${ }^{1}$ Louis E. Boone, Pengantar Bisnis Kontemporer (Jakarta: Salemba Empat, 2013), 157.

${ }^{2}$ Noor Shodiq Askandar, 99 Great Ways Menjadi Pengusaha Muslim Sukses (Jakarta: Erlangga, 2013), 176. bertransaksi, yaitu penjual dengan konsumennya. $^{3}$

Konsentrasi terhadap pasar telah mendapatkan perhatian memadai dari para ulama klasik seperti Ibn Khaldun. Ibn Khaldun menggunakan konsep-konsep mekanisme pasar ini untuk membangun suatu sistem yang dinamis dan koheren. Secara khusus Ibn Khaldun fokus kepada penentuan harga yang disebabkan oleh adanya permintaan dan penawaran. ${ }^{4}$ Ibn Khaldun juga sangat menghargai harga yang terjadi dalam pasar bebas, namun ia tidak mengajukan saran-saran kebajikan pemerintah untuk mengelola harga. Ia lebih banyak memfokuskan kepada faktor-faktor yang mempengaruhi harga. Menurut Ibn Khaldun, seluruh aktivitas ekonomi pada dasarnya dibolehkan, kecuali yang secara tegas dilarang oleh syari'at. Batasan syari'at dapat diketahui dari kebebasan dalam menjalankan segala macam bentuk aktivitas transaksi dengan tetap memelihara keadilan dan kejujuran. ${ }^{5}$

Untuk itu maka penulis merasa perlu untuk mengkaji lebih dalam lagi mengenai 1) Bagaimana mekanisme pasar menurut teori Ibn Khaldun? 2) Apa produk usaha kreatif home industri di desa Bodelor? 3) Bagaimana relevansi dari pemikiran Ibn Khaldun dengan mekanisme pasar produk usaha kreatif home industri yang ada di desa Bodelor?

\section{LITERATUR REVIEW}

Berikut beberapa karya yang terdokumentasikan terkait permasalahan yang dikaji, yaitu pertama, penelitian yang dilakukan oleh Zuliati, Nanik Ermawati, dan Hutomo

\footnotetext{
${ }^{3}$ Teguh Santoso, Marketing Strategic (Yogyakarta: Oryza, 2011), 11.

${ }^{4}$ Muhammad Furqon, "Pemikiran Ekonomi Ibn Khaldun dalam Mekanisme Pasar", dalam http://eprints.ums.ac.id/30877/. Diakses pada tanggal 23 Oktober 2017.

${ }^{5}$ Euis Amalia, Keadilan Distributif dalam Ekonomi Islam (Jakarta: Rajawali Pers, 2009), 109.
} 
Rusdianto $^{6}$ mengatakan bahwa ekonomi kreatif adalah ekonomi yang didukung oleh industri kreatif, yaitu industri yang digerakkan oleh para kreator dan inovator. Berkembangnya industri kreatif di Indonesia diharapkan dapat memotivasi warga Indonesia untuk berkembang dan bergelut dalam industri kreatif.

Kedua, Nurul Huda ${ }^{7}$ dalam karyanya "Harga dan Mekanisme Pasar" mengatakan secara alamiah harga ditentukan oleh peran mekanisme pasar melalui keseimbangan antara permintaan dan penawaran di pasar. Pada dataran tertentu, intervensi pemerintah dibutuhkan untuk menjaga stabilitas harga, yaitu ketika terganggu tindakan distortif oleh para pelaku ekonomi yang sengaja ingin mengacaukan harga pasar. Sebagai pelaksananya diserahkan kepada institusi hisbah yang memiliki tugas khusus sebagai badan pengawas pasar yang selalu aktif memantau perkembangan fluktuasi harga di pasar. Dengan adanya hisbah diharapkan mekanisme pasar dapat berjalan normal dan harga yang terbentuk mencerminkan aspek keadilan bagi pelaku pasar.

Ketiga, Aan Jaelani dalam karyanya "Hisbah and Market Mechanism: The Morality Study of Market Participants in Islamic Economic Perspective". ${ }^{8}$ Peran pemerintah dalam mekanisme pasar perlu mendapatkan perhatian utama

${ }^{6}$ Zuliati, et.al., "Pengembangan Wirausaha Industri Kreatif Melalui Inovasi Produk Berbasis Syariah", dalam http://dppm.uii.ac.id/. Diakses pada tanggal 02 Maret 2017.

${ }^{7}$ Nurul Huda, "Harga dan Mekanisme Pasar", dalam http://publikasiilmiah.ums.ac.id. Diakses pada tanggal 23 Oktober 2017.

${ }^{8}$ Aan Jaelani, "Hisbah and Market Mechanism: The Morality Study of Market Participants in Islamic Economic Perspectiv", dalam https://mpra.ub.uni-muenchen.de/69526/. Diakses pada tanggal 02 Maret 2017. tanpa mengorbankan potensi manusia dalam mengembangkan aktivitas ekonomi. Salah satu peran pemerintah dalam mengatur mekanisme pasar terkait dengan penentuan harga adalah menetapkan lembaga pengawas pasar (market supervision) atau disebut "hisbah". Keberadaan institusi hisbah dalam mengawasi proses mekanisme pasar dengan peran untuk mengontrol moralitas pelaku pasar dan harga dalam konteks mewujudkan kesejahteraan ekonomi dan keadilan. Hisbah (lembaga resmi negara) yang diberi wewenang untuk menyelesaikan masalah-masalah atau pelanggaran ringan. Peran hisbah ini memberikan jaminan bagi masyarakat muslim dalam berwirausaha.

Dari ketiga topik penelitian yang telah dipaparkan di atas, peneliti melihat ketiganya sangat penting dalam penyusunan penelitian ini sebagai gambaran awal mengenai penyampaian hasil penelitian yang didapat dengan menggunakan teori dari Ibn Khaldun.

\section{METODOLOGI PENELITIAN}

Penelitian yang digunakan dalam penulisan ini adalah penelitian deskriptif yaitu penelitian yang menggambarkan data dan informasi di lapangan berdasarkan fakta yang diproses di lapangan secara mendalam. ${ }^{9}$ Dalam metode ini, penelitian dimaksudkan untuk melakukan penggambaran mengenai situasi-situasi dan kejadian-kejadian. $^{10}$ Pendapat lain mengatakan bahwa penelitian kualitatif adalah jenis penelitian yang temuantemuannya tidak diperoleh melalui prosedur statistik atau bentuk hitungan lainnya. ${ }^{11}$ Dalam penelitian ini peneliti menggunakan

\footnotetext{
${ }^{9}$ Suharmi Arikunto, Management Penelitian (Jakarta: Rineka Cipta, 1993), 309.

${ }^{10}$ Sumardi Suryabrata, Metedologi Penelitian (Jakarta: Raja Grafindo, 2004), 76.

${ }^{11}$ Boedi Abdullah dan Beni Ahmad Saebani, Metode Penelitian Ekonomi Islam (Muamalah) (Bandung: Pustaka Setia, 2014), 49.
} 
pendekatan kualitatif-deskriptif. Data yang dikumpulkan adalah kata-kata, gambar dan bukan angka-angka. Hal itu disebabkan oleh adanya penerapan metode kualitatif.

Dalam penelitian ini, sumber data yang digunakan adalah sumber data primer dan sekunder. Data primer adalah data utama yang diperoleh secara langsung dari lapangan. Data primer diperoleh dari wawancara dengan beberapa pengrajin usaha kreatif industri rumahan yang terdapat di desa Bodelor yang mengetahui secara langsung tentang masalah yang sedang dibahas. Data sekunder adalah data yang diperoleh secara tidak langsung dalam sumbernya yaitu diperoleh dari pihak lain, bukan dari subjek penelitian. Data sekunder diperoleh dari kasi pemerintah desa dan sekretaris desa. Data sekunder bisa berwujud data dokumentasi atau data laporan yang telah tersedia, serta arsip-arsip resmi.

Metode pengumpulan data yang digunakan adalah observasi, wawancara dan dokumentasi. Pertama, observasi adalah pengamatan atas suatu variable yang dilakukan secara sistematis dan objektif dalam kondisi yang didefinisikan secara tepat dan hasilnya dicatat secara hati-hati. ${ }^{12}$ Observasi digunakan untuk memperoleh data informasi dari pengrajin usaha kreatif secara langsung agar didapatkan data yang valid dan juga kepada kepala desa Bodelor, yang sudah pasti mengetahui keadaan yang sebenarnya di lingkungan desanya.

Kedua, wawancara adalah percakapan dengan maksud tertentu. Percakapan itu dilakukan oleh dua pihak, yaitu pewawancara yang mengajukan pertanyaan dan yang diwawancarai yang memberikan jawaban atas pertanyaan itu. ${ }^{13}$ Dalam teknik ini, peneliti bertanya langsung dengan para wirausahawan industri rumahan dan para pengrajin.

${ }^{12}$ Lerbin R. dan Ariotang R., Riset Pemasaran (Jakarta: Ghalia Indonesia, 2007), 147.

${ }^{13}$ Lexy J. Moeloeng, Metodologi Penelitian Kualitatif (Bandung: Remadja Karya, 1986), 148.
Ketiga, studi kepustakaan atau penelitian kepustakaan (library research) yaitu dengan melakukan penelitian terhadap berbagai literature dan dilakukan untuk mencari konsep yang ada relavasinya dengan topik pembahasan melalui pengkajian buku-buku, modul, jurnal, surat kabar dan majalah, serta pendapat-pendapat para ahli secara tidak langsung.

Analisis data yang digunakan dalam penelitian adalah dengan cara analisis kualitatif. Dalam hal ini pemaparan kembali dengan kalimat yang sistematis memberikan gambaran secara jelas, jawaban atas permasalahan dalam uraian ini. ${ }^{14}$ Pengamatan berperan serta dalam mewujudkan wawancara secara mendalam, yang dapat pula dilengkapi dengan analisis dokumen. Namun, sebagian besar penelitian hanya mengandalkan dokumen-dokumen tanpa dilengkapi dengan wawancara, meskipun dokumen merupakan sumber primer penelitian. Data yang dilengkapi dengan dokumen ini sebaiknya dilengkapi dengan data yang diperoleh lewat wawancara dengan pihak-pihak terkait.

Proses analisis data dimulai dengan menelaah seluruh data yang tersedia dari berbagai sumber, yaitu wawancara, pengamatan yang sudah dituliskan dalam catatan lapangan, dokumen pribadi, dokumen resmi, gambar, foto dan sebagainya. Langkah berikutnya adalah mengadakan reduksi data yang dilakukan dengan jalan abstraksi. Abstraksi merupakan usaha membuat rangkuman yang inti dan proses pertanyaan-pertanyaan yang perlu dijaga sehingga tetap berada di dalamnya.

Selanjutnya adalah menyusun dalam satuan-satuan, dan dilanjutkan pada tahap terakhir yaitu mengadakan pemeriksaan keabsahan data. Setelah selesai tahap ini, mulailah tahap penafsiran data dalam mengolah hasil sementara menjadi teori

\footnotetext{
${ }^{14}$ Mulyana Deddy, Metodologi Penelitian Kualitatif (Bandung: Remaja Rosdakarya, 2011), 195.
} 
substansif dengan menggunakan beberapa metode tertentu.

\section{KONSEP DASAR}

\section{Mekanisme Pasar dalam Perspektif Teori Ibn Khaldun}

Sebelum kita membahas mekanisme pasar Ibn Khaldun, peneliti akan menjabarkan tentang definisi pasar dan stuktur pasar secara umum. Pasar (market) merupakan suatu tempat di mana pembeli dan penjual bertemu untuk membeli atau menjual barang dan jasa. Dalam bahasa sehari-hari, pasar pada umumnya diartikan sebagai suatu lokasi geografis (geographic location). Tetapi dalam pengertian teori ekonomi mikro adalah lebih luas lagi. Pasar meliputi "pertemuan" antara pembeli dan penjual, di mana antara keduanya mungkin tidak saling melihat satu sama lain (misalnya antara importir karet yang bertempat tinggal di Amerika dan eksportir karet di Indonesia yang melakukan transaksi jual beli melalui telepon dan internet). Sesuai dengan firman Allah SWT dalam surat Al-Furqan ayat $20:^{15}$

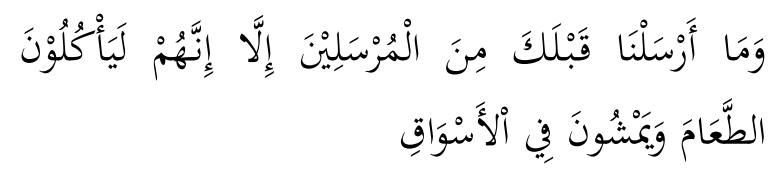

Artinya: Dan kami tidak mengutus rasul-rasul sebelummu, melainkan mereka sungguh memakan makanan dan berjualan di pasar-pasar". 16

Pasar merupakan tulang punggung perekonomian masyarakat, baik masyarakat yang berada di kalangan kelas bawah ataupun masyarakat yang berada di kalangan kelas atas. Semua unsur yang berkaitan dengan hal ekonomi berada di pasar, mulai dari unsur produksi, distribusi, ataupun unsur konsumsi. Aktivitas yang dilakukan di pasar pada dasarnya akan melibatkan produsen dan konsumen. Masing-masing dari mereka mempunyai

\footnotetext{
${ }^{15}$ QS. Al-Furqan (25): 20.

${ }^{16}$ Al-Qur'an Al-Hidayah, Tafsir Perkata Tajwid Kode Angka (Tanggerang: Kalim, 2010), 362.
}

peranan yang sangat penting terhadap pembentukan harga dalam pasar. ${ }^{17}$

Mekanisme pasar adalah cara bekerja suatu pasar berdasarkan pada sistem pasar yang ada. Dan sistem pasar yang kita kenal saat ini adalah sistem pasar bebas yang biasa menggunakan prinsip lassez faire et lassez le monde van de lui meme (biarkan ia berbuat dan biarkan ia berjalan, dunia akan mengurus dirinya sendiri). ${ }^{18}$

Mekanisme pasar terjadi akibat adanya kecenderungan dalam pasar bebas untuk terjadinya perubahan harga sampai pasar menjadi seimbang (jumlah yang ditawarkan sama dengan jumlah yang diminta). Dengan sejumlah kondisi yang diisyaratkan, mekanisme pasar dianggap sebagai mekanisme yang dapat mendorong pemakaian sumber daya yang efisien dan dapat mendorong perkembangan ekonomi karena adanya kebaikan dalam mekanisme pasar. $^{19}$

Menurut Ibn Khaldun, mekanisme pasar adalah sebuah sistem yang menentukan terbentuknya harga, yang di dalam prosesnya dapat dipengaruhi oleh berbagai hal, yaitu permintaan dan penawaran, distribusi, kebijakan pemerintah, pekerja, uang, pajak dan keamanan. Dalam proses mekanisme pasar tersebut diharuskan adanya asas moralitas, yang antara lain persaingan yang sehat (fair play), kejujuran (honesty), keterbukaan (transparancy) dan keadilan (justice). Jika nilai-nilai ini telah ditegakkan maka tidak ada alasan untuk menolak harga pasar. ${ }^{20} \mathrm{Ibn}$ Khaldun memulai membahas mengenai fenomena harga di pasar, yang menurutnya

\footnotetext{
${ }^{17}$ Linda Nelistya, "Pasar Monopolistik", dalam http://www.academia.edu. Diakses pada tanggal 22 Maret 2017.

${ }^{18}$ Adiwarman A. Karim, Ekonomi Mikro Islami (Jakarta: PT RajaGrafindo Persada, 2008), 145.
${ }^{19}$ Nophirin, Pengantar Ekonomi Makro (Yogyakarta: BPEE, 2012), 346.
${ }^{20}$ M. Arifin, "Studi Komparatif tentang Mekanisme Pasar Ibnu Khaldun dan Adam Smith", dalam http://digilib.uinsby.ac.id/1981/. Diakses pada tanggal 23 Oktober 2017.


bergantung kepada beberapa faktor. Faktorfaktor ini, menurut Ibn Khaldun mempengaruhi tingkat harga. ${ }^{21}$

\section{Hukum permintaan dan penawaan}

Ibnu Khaldun mengakui adanya pengaruh permintaan dan penawaran terhadap penentuan harga, jauh sebelum konsep tersebut dikenal di Barat. Istilah permintaan dan penawaran baru dikenal dalam literatur bahasa Inggris pada tahun 1767. Akan tetapi peranan dan fungsi dari permintaan dan penawaran dalam penentuan harga di pasar baru dikenal pada dekade kedua di abad ke 19. Hal ini sangat penting untuk diketahui karena peranan permintaan dan penawaran terhadap penentuan harga tidak begitu baik difahami di dunia barat sampai akhir abad ke-19 dan ke-20. Ibnu Khaldun menekankan bahwa kenaikan penawaran atau penurunan permintaan menyebabkan kenaikan harga, demikian pula sebaliknya. Ia percaya bahwa akibat dari rendahnya harga akan merugikan perajin dan pedagang, sehingga mereka keluar dari pasar, sedangkan akibat dari tingginya harga akan menyusahkan konsumen, terutama kaum miskin yang menjadi mayoritas dalam sebuah populasi. ${ }^{22}$

Teori Ibnu Khaldun tentang supply and demand diilustrasikan oleh Adiwarman Karim, sebagai berikut :

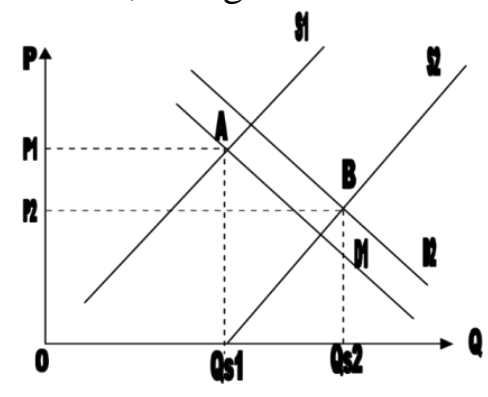

Grafik di samping menjelaskan tentang tingkat harga bahan pokok di kota

\footnotetext{
${ }^{21}$ Muslim, "Mekanisme Harga Menurut Pemikiran Ibnu Khaldun", dalam http://repository.uin-suska.ac.id/2010. Diakses pada tanggal 23 Oktober 2017.

${ }^{22}$ Husna N. Ulya, "Permintaan, Penawaran dan Harga Perspektif Ibnu Khaldun", dalam http://jurnal.stainponogoro.ac.id. Diakses pada tanggal 05 April 2017.
}

besar dan kota kecil. Supply bahan pokok penduduk kota besar $\left(\mathrm{Qs}_{2}\right)$ jauh lebih besar dari pada supply bahan pokok di kota kecil $\left(\mathrm{Qs}_{1}\right)$.

Menurut Ibn Khaldun, penduduk kota besar memiliki supply bahan pokok yang melebihi kebutuhannya sehingga harga bahan pokok di kota besar relatif lebih murah $\left(\mathrm{P}_{2}\right)$. Sementara itu supply bahan pokok di kota kecil relatif sedikit sehingga permintaan tinggi karena penduduk kota kecil khawatir kehabisan bahan makanan pokok dan imbasnya harga menjadi lebih tinggi $\left(\mathrm{P}_{1}\right){ }^{23}$

Ibn Khaldun mengklasifikasikan beberapa faktor yang mempengaruhi hukum permintaan dan penawaran, diantaranya; pertama, perbedaan antara kebutuhan manusia (primer dan sekunder); kedua, faktor perbedaan jumlah penduduk; ketiga, perbedaan kondisi pasar. Ketiganya merupakan faktor penting yang saling berpengaruh dalam proses menentukan harga. $^{24}$

\section{Pemerintah}

Dalam bukunya Ibn Khaldun yang berjudul Muqaddimah bab III pasal "perdagangan yang dilakukan raja dan Negara berbahaya dan merusak pendapatan rakyat", dijelaskan bahwa pada mulanya para pelaku perdagangan dan pertanian berada dalam sebuah mekanisme yang mempunyai kedudukan yang sama atau hampir dalam kekayaan dan kekuasaan. Dalam kondisi demikian, price competition dan mekanisme pasar dapat berjalan dengan sempurna. Tapi ketika pemerintah ikut ambil bagian dalam perdagangan dan pertanian maka normalitas ini akan rusak, Karena bagaimanapun juga pemerintah akan berusaha untuk menguasainya, memproduksi, menjual dan membeli hasil produksi dengan kehendak

\footnotetext{
${ }^{23}$ Euis Amalia, Sejarah Pemikiran Ekonomi Islam (Depok: Gramata Publishing, 2010), 237-238.

${ }^{24}$ Nurul Huda, "Harga dan Mekanisme Pasar", dalam http://publikasiilmiah.ums.ac.id. Diakses pada tanggal 23 Oktober 2017.
} 
sendiri tanpa memperdulikan keadaan pasar dan keadilan harga. ${ }^{25}$

Secara umum Ibnu Khaldun sangat menekankan pentingnya suatu sistem pasar yang bebas. Ia menentang intervensi negara terhadap masalah ekonomi dan percaya akan efisiensi sistem pasar bebas. Harga sangat ditentukan oleh permintaan dan penawaran. Penurunan harga menyebabkan kerugian produsen, dan sebaliknya kenaikan harga akan menyusahkan konsumen. Dengan demikian, tingkat harga yang stabil dengan biaya hidup yang relatif rendah menjadi pilihan bagi masyarakat dengan sudut pandang pertumbuhan dan keadilan dengan perbandingan masa inflasi dan deflasi. Inflasi akan merusak keadilan, sedangkan deflasi akan mengurangi insentif dan efisiensi. Harga rendah untuk kebutuhan pokok seharusnya tidak dicapai dengan penetapan harga baku oleh negara, karena hal itu akan merusak insentif bagi produksi. $^{26}$

\section{Pekerja}

Ibnu Khaldun mendefinisikan keuntungan sebagai nilai kerja yang mesti dibayar dan tercermin pada harga sesuatu komoditi/barang. Ini bermaksud bahwa harga dasar suatu barang itu mengambarkan biaya produksinya, sedangkan marginnya adalah upah yang mesti dibayar oleh pembeli kepada produsen yang menghasilkan komoditi/barang tersebut.Ibnu khaldun menyebutkankata "kasab" sebagai nilai dari tenaga manusia. ${ }^{27}$

Ibn Khaldun mengatakan, "Pendapatan yang dinikmati seseorang sesungguhnya merupakan nilai dari

\footnotetext{
${ }^{25}$ Muslim, "Mekanisme Harga Menurut Pemikiran Ibnu Khaldun", dalam http://repository.uin-suska.ac.id/2010. Diakses pada tanggal 23 Oktober 2017.

${ }^{26}$ Husna N. Ulya, "Permintaan, Penawaran dan Harga Perspektif Ibnu Khaldun", dalam http://jurnal.stainponogoro.ac.id. Diakses pada tanggal 05 April 2017.

${ }^{27}$ Abdullah Zakiy Al-Kaaf, Ekonomi dalam Perspektif Islam (Bandung: Pustaka Setia, 2002), 21.
}

kerjanya. Andaikan saja seseorang sepenuhnya tidak memiliki pekerjaan (shina'ah) niscaya ia akan kehilangan pendapatan sepenuhnya." Jadi, menurut Ibn Khaldun faktor yang menentukan nilai barang-barang produksi adalah kuantitas kerja yang dicurahkan kepadanya. ${ }^{28}$ Konsep ini cukup rasional dan sangat jelas dimana Ibn Khaldun mampu untuk memisahkan harga menjadi harga dasar dan harga keuntungan dengan sangat tepat dan beralasan. Pendapat ini juga menggambarkan penghargaan yang tinggi terhadap nilai kerja seseorang. ${ }^{29}$

\section{Pajak}

Faktor yang mempengaruhi harga menurut pengamatan Ibn Khaldun adalah kebijaksanaan atau peraturan dari pihak pemerintah yang tersimpul dalam kebijakan kebijakan yang dapat mempengaruhi produksi dan suplai, seperti kebijakan fiskal, pajak, dan bea cukai sebagaimana katanya bahwa "bea cukai biasa, dan bea cukai lainnya dipungut atas beban makanan di pasar-pasar dan di pintu-pintu kota demi raja, dan para pengumpul pajak menarik keuntungan dari transaksi bisnis untuk kepentingan mereka sendiri. Karenanya, harga di kota lebih tinggi daripada di padang pasir".

Statemen Khaldun ini mengingatkan bahwa pajak terhadap sesuatu komoditi dapat dihitung sebagai beban produksi atau kerja. Ini menyebabkan harga barang tersebut menjadi lebih mahal dalam pemasarannya berbanding dengan harga pasar barangan tersebut di tempat-tempat

\footnotetext{
${ }^{28}$ Asep Udin, "Teori Permintaan dan Penawaran Ibnu Khaldun", dalam www.academia.edu. Diakses pada tanggal 09 April 2017.

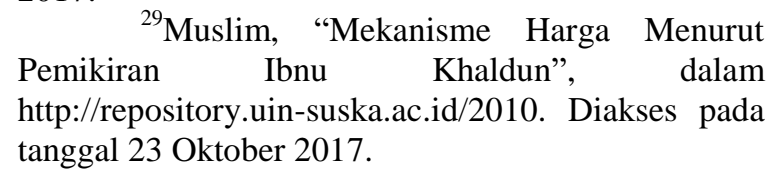


yang tidak menetapkan bea masuk terhadap barang itu. ${ }^{30}$

\section{Uang}

Ibnu Khaldun hidup di jaman di mana mata uang sudah menjadi alat penghargaan. Pada masa itu ia sudah membicarakan kemungkinan yang bakal terjadi tentang kedudukan yang selanjutnya dari mata uang. Dia menulis sebagai berikut: "Sesudah demikian, Allah telah menjadikan pula dua barang galian yang berharga, ialah emas dan perak menjadi bernilai di dalam perhubungan ekonomi. Keduanya menurut kebiasaan menjadi alat perhubungan dan alat simpanan bagi penduduk dunia. Jika terjadi alat perhubungan dengan yang lainnya pada beberapa waktu, maka tujuan yang utama tetap untuk memiliki kedua benda itu di dalam peredaran harga-harga pasar, karena keduanya terjauh dari pasar itu."

Akhirnya Ibnu Khaldun meramalkan bahwa kedua barang galian ini nanti akan mengambil tempat yang terpenting di dalam dunia perekonomian, ialah melayani tiga kepentingan, yaitu: pertama, menjadi alat penukar dan pengukur harga, sebagai nilai usaha (makasib); kedua, menjadi alat perhubungan, seperti deviezen (qaniah); dan ketiga, menjadi alat simpanan di dalam bank-bank (zakhirah). ${ }^{31}$

\section{Keamanan}

Peran pemerintah dalam mekanisme pasar perlu mendapatkan perhatian utama tanpa mengorbankan potensi manusia dalam mengembangkan aktivitas ekonomi. Sedangkan menurut Ibnu Khaldun dalam Muqaddimah-nya pemerintah memiliki

\footnotetext{
${ }^{30}$ Muslim, "Mekanisme Harga Menurut Pemikiran Ibnu Khaldun", dalam http://repository.uin-suska.ac.id/2010. Diakses pada tanggal 23 Oktober 2017.

${ }^{31}$ Choirul Huda, "Pemikiran Ekonomi Bapak Ekonomi Islam Ibnu Khaldun", dalam http://journal.walisongo.ac.id. Diakses pada tanggal 27 Februari 2017.
}

tugas yang berkaitan dengan masalah ekonomi. $^{32}$

Ibn Khaldun sangat menekankan pada peran negara, karena menurutnya negara adalah pemegang otoritas tunggal yang berkuasa sepenuhnya atas aspek kehidupan masyarakat. Dalam perekonomian ibnu khaldun berpandangan bahwa antara satu individu dengan lainnya tersusun dalam suatu komunitas bersama dalam wujud negara yang mengatur tatanan seluruh aspek kehidupan, hal ini seiring dengan keberadaan mereka sebagai makhluk sosial yang tak mungkin bagi mereka untuk melakukan suatu pekerjaan tanpa iringan bantuan yang lain dankebersamaan antara individu menjadi sangat penting. Bentuk kebersamaan tersebut tertuang dalam wujud negara yang mempunyai pemerintahan yang berkuasa atas setiap serangan dan gangguan yang mencoba menggoyahkan sendi-sendi utama negara dan rakyatnya. ${ }^{33}$

\section{Memahami Arti Usaha Kreatif}

Usaha adalah kegiatan dengan mengerakan tenaga, pikiran, atau badan untuk mencapai suatu maksud; pekerjaan (perbuatan, prakarsa, ikhtiar, daya upaya) untuk mencapai sesuatu. ${ }^{34}$ Membuka usaha atau berusaha adalah sesuatu yang sangat beresiko dan penuh ketidakpastian, namun di balik itu ada potensi yang menjanjikan bila usaha tersebut berhasil. Semuanya mungkin dan pasti akan terjadi. Adakalanya untung dan adakalanya rugi. Untung rugi adalah hal yang biasa, artinya tidak ada jaminan bahwa setiap usaha atau bisnis selalu mendatangkan keuntungan. Resiko

\footnotetext{
${ }^{32}$ M. Arifin, "Studi Komparatif tentang Mekanisme Pasar Ibnu Khaldun dan Adam Smith", dalam http://digilib.uinsby.ac.id/1981/. Diakses pada tanggal 23 Oktober 2017.

${ }^{33}$ Suhaimi, "Pemikiran Ibnu Khaldun tentang Perdagangan, Rasio Keuntungan dan Mekanisme Pengawasan Pasar dalam Kitab Al-Muqaddimah", dalam http://respository.uin-suska.ac.id. Diakses pada tanggal 15 Juni 2017.

${ }^{34}$ http://kbbi.web.id/usaha. Diakses pada tanggal 17 Mei 2017.
} 
senantiasa ada di manapun. ${ }^{35}$ Agar perusahaan unggul haruslah inovatif, dan mesinnya adalah kreativitas SDM. Pekerja dalam industri kreatif ini mensyaratkan keaslian, keunikan, dan ketrampilan teknis profesional dari hasil kerja mereka. Saat kreativitas itu datang, di sanalah peluang bagi anda untuk mewujudkan dan mengomersialkannya. Yakinlah tidak semua orang bisa melakukannya. Jadi, jangan menunda-nunda lagi jika sudah menemukan peluang untuk melakukan sebuah bisnis. ${ }^{36}$

Kata "kreatif" saat ini seringkali terdengar, khususnya bagi mereka yang menciptakan produk baru, atau melakukan pengembangan pada produk yang sudah kita kenal sebelumnya.Kreativitas berkaitan dengan kemampuan menghadirkan ide-ide baru dan unik yang menghasilkan nilai tambah bagi perusahaan. Tenaga-tenaga kreatif adalah aset yang menjadi sumber utama keunggulan bersaing. Oleh karenanya mengelola karyawan kreatif dalam perusahaan sama pentingnya dengan menumbuhkan kreativitas itu sendiri. Ideide segar serta perspektif baru yang mereka miliki, seringkali menghasilkan aneka trobosan bagi produk, cara kerja yang lebih efektifdan efisien. Karyawan harus diberi kebebasan dan kepercayaan yang lebih luas untuk mengekspresikan, memikirkan, menelusuri, mempertanyakan, serta mencoba ide-ide baru. ${ }^{37}$ Melihat kreativitas sebagai produk merupakan upaya mendefinisikan kreativitas yang berfokus pada produk atau apa yang dihasikan oleh individu baik sesuatu yang baru/original atau sebuah elaborasi/penggabungan yang inovatif.

\footnotetext{
${ }^{35}$ Leonardus Saiman, Kewirausahaan Teori, Praktik dan Kasus-kasus (Jakarta: Salemba Empat, 2009), 76.

${ }^{36}$ Indari Mastuti dan Agustin Rozalena, Mencicipi Kesuksesan Amanda Brownis Kukus (Bandung: Kaifa, 2010), 90.

${ }^{37}$ A. B. Susanto, Management For Everyone 5 Human Capital (Jakarta: Erlangga, 2011), 105106.
}

\section{Home Industri}

Home berarti rumah, tempat tinggal, ataupun kampung halaman. Sedang Industry, dapat diartikan sebagai kerajinan, usaha produk barang dan ataupun perusahaan. Singkatnya, Home Industry (atau biasanya ditulis/dieja dengan "Home Industri") adalah rumah usaha produk barang atau juga perusahaan kecil. Dikatakan sebagai perusahaan kecil karena jenis kegiatan ekonomi ini dipusatkan di rumah.

Dikatakan sebagai perusahaan kecil karena jenis kegiatan ekonomi ini dipusatkan di rumah. Pengertian usaha kecil secara jelas tercantum dalam UU No. 9 Tahun 1995, yang menyebutkan bahwa usaha kecil adalah usaha dengan kekayaan bersih paling banyak Rp. 200 juta (tidak termasuk tanah dan bangunan tempat usaha) dengan hasil penjualan tahunan paling banyak Rp1.000.000.000. Kriteria lainnya dalam UU No 9 Tahun 1995 adalah: milik WNI, berdiri sendiri, berafiliasi langsung atau tidak langsung dengan usaha menengah atau besar dan berbentuk badan usaha perorangan, baik berbadan hukum maupun tidak. Home Industri juga dapat berarti industri rumah tangga, karena termasuk dalam kategori usaha kecil yang dikelola keluarga.

Home industri adalah kegiatan pengolahan bahan mentah atau barang setengah jadi menjadi barang jadi yang memiliki nilai tambah untuk mendapatkan keuntungan. $^{38}$ Dalam proses ekonomi dikenal adanya pembagian secara khusus, yakni proses produksi dan proses distribusi atau tukar menukar. Pada kenyataannya, manusia senantiasa menghadapi kelangkaan barang dan jasa dalam mencoba memenuhi kebutuhan hidupnya. Secara ekonomis, pemenuhan kebutuhan hidup tersebut harus

\footnotetext{
${ }^{38}$ Siti Susana, "Peran Home Industri dalam Meningkatkan Kesejahteraan Masyarakat Menurut Perspektif Ekonomi Islam", dalam https://repository.uin-suska.ac.id. Diakses pada tanggal 04 Maret 2017.
} 
dilakukan oleh manusia dengan pengeluaran yang semaksimal mungkin. Dalam konteks seperti itu maka kegiatan atau proses produksi menjadi penting dalam proses ekonomi secara keseluruhan, disamping proses distribusi yang menjadi mata rantai yang tak terpisahkan.

Seseorang pengusaha yang semula melaksanakan aktivitasnya dalam lingkungan sebuah home industry, dengan sendirinya harus menyesuaikan dengan kondisi-kondisi dan syarat-syarat yang diperlukan untuk menjalankan produksi didalam lingkungan sebuah factory. ${ }^{39}$ Dalam dunia usaha, ada dua jenis produksi yang dikenal. Yaitu produksi secara massal dan secara customize. Produksi massal biasanya dilakukan untuk barang-barang yang digunakan secara umum oleh masyarakat. Artinya kebutuhan setiap masyarakat terhadap produk tersebut adalah sama. Berbeda dengan produk customize, yang diproduksinya tergantung pesanan konsumen. Sehingga konsumen bisa memesan sesuai dengan keingginannya, entah itu dari modelnya atau warnanya. ${ }^{40}$

\section{PEMBAHASAN DAN DISKUSI \\ Mekanisme Pasar Perspektif Ibn Khaldun}

Untuk melihat bagaimana mekanisme pasar yang ada di desa Bodelor, peneliti akan melihatnya menggunakan teori pemikiran Ibn Khaldun mengenai mekanisme pasar.

Mekanisme pasar sendiri menurut Ibn Khaldun ialah sebuah proses terbentuknya harga yang dilihat dari beberapa faktor diantaranya permintaan dan penawaran, distribusi, pemerintah, pekerja, pajak, uang dan keamanan. Dari beberapa faktor yang ada, peneliti akan membaginya dalam 3 (tiga) teori sesuai dengan pemikiran Ibn Khaldun tentang mekanisme pasar, yaitu

\footnotetext{
${ }^{39}$ Jozef Winardi, Peran Usahawan dalam Pembangunan Indonesia (Bandung: Tarsito, 1977), 16.

${ }^{40}$ Enni K. Hairuddin, Kreatif Mencipta Produk (Jakarta: Progressio, 2016), 42.
}

pertama, teori tentang harga. Berdasarkan hasil interview dengan beberapa home industri yang ada di desa Bodelor menurut ibu Baeriyah selaku pemilik home industri rotan, dalam sitem penentuan harga, permintaan dan penawaran menjadi salah satu faktor di dalamnya. Menurutnya, "harga naik saat bahan baku rotan susah didapatkan dan permintaan akan kerajinan rotan banyak, sedangkan penurunan harga cenderung tidak pernah terjadi. Tetapi dalam produk tertentu seperti kursi mio mengalami penurunan. Harga awal muncul produk ini Rp. 70.000,00 dan sekarang harga turun menjadi Rp. 45.000,00". ${ }^{41}$ Dari penuturan ibu Baeriyah tersebut, produk kursi mio ini mengalami penurunan karena banyaknya para produsen yang membuat produk tersebut. Proses pembuatan kursi mio ini jauh lebih mudah dibandingkan dengan produk lain, karena bahan rotan pembuatannya mudah didapat serta lebih cepat dalam pembuatannya karena rotan yang digunakan masih "rotan asalan" rotan asli yang berkulit.

Sedangkan bagi para pemilik home industri kerai bambu, menurut ibu Dewi Tuti selaku istri dari Bapak Bukhori pemilik kerajinan kerai bambu, mengatakan: ${ }^{42}$ "Sejauh ini permintaan produk kerai cenderung stabil, tidak ada istilah 'mremaan' untuk produk kerai. Kenaikan harga itu terjadi akibat kurangnya pasokan produk kerai untuk di pasarkan".

Lain halnya dengan produk usaha konveksi yang ada di desa Bodelor, dari beberapa hasil wawancara dengan para usaha konveksi, faktor permintaan dan penawaran menjadi salah satu penentu terbentuknya harga, karena ketika permintaan tinggi penawaran akan barang tersebut berkurang, harga akan naik sebaliknya jika penawaran tinggi akan barang tapi permintaan rendah, harga barang

\footnotetext{
${ }^{41}$ Hasil wawancara dengan Ibu Baeriyah, Pengusaha Rotan pada tanggal 17 Mei 2017.

${ }^{42}$ Hasil wawancara dengan Ibu Dewi Tuti, Pengusaha Kerai Bambu pada tanggal 15 Juli 2017.
} 
tersebut akan turun. Untuk usaha konveksi mukenah perkembangan model produknya tidak terlalu signifikan sehingga cenderung tidak pernah mengalami penurunan harga, berbeda dengan produk kerudung yang selalu mengikuti trend fashion. Jika para produsen tidak 'up to date' akan produk yang meningkat dipasaran, akan mengurangi omset penjualan mereka. Tapi sebaliknya jika tidak bisa mengikuti trend sekarang, permintaan akan barang produknya berkurang sehingga menimbulkan terjadinya penumpukan barang produksi, selanjutnya dengan tenggang waktu tertentu akan dilakukannya pengobralan barang.

Kedua, teori nilai. Berdasarkan hasil interview dengan beberapa home industri (kerajinan rotan, kerai bambu, kerudung dan mukenah) yang ada di desa Bodelor. Menurut ibu Dewi Tuti "Para pekerja sangat menentukan hasil produksi kerai bambu. Jika mereka produktif dalam membuat produk omset akan bertambah". ${ }^{43}$ Usaha para pekerja dalam membuat produk sangat dihargai oleh para pemilik home industri sesuai dengan keahlian yang dimilikinya, salah satunya ialah dengan pemberian upah yang sesuai dengan porsi kerjanya juga terdapat tambahan tunjangan hari raya (THR) setiap tahunnya. ${ }^{44}$

Dan ketiga, pemerintah. Berdasarkan hasil interview dengan beberapa home industri di desa Bodelor, yang dirasakan oleh ibu $\mathrm{Hj}$. Yama mengenai bentuk intervensi dari pemerintah, bahwa pemerintah tidak ikut andil dalam berjalannya mekanisme pasar. Menurutnya, home industri yang ada hanya berupa usaha kecil menengah jadi tidak perlu adanya campur tangan pemerintah. Dari pemerintah daerah sendiri belum adanya perhatian dari pemerintah untuk menempatkan secara khusus wadah (tempat) dalam menjual

\footnotetext{
${ }^{43}$ Hasil wawancara dari Ibu Dewi Tuti, Pengusaha Kerai Bambu pada tanggal 17 Juli 2017.

${ }^{44} \mathrm{Hasil}$ wawancara dengan $\mathrm{Ibu} \mathrm{Hj}$. Yama, Pemilik Usaha Konveksi Kerudung pada tanggal 26 Februari 2017.
}

produk yang dihasilkan oleh home industri ini.

\section{Produk Usaha Kreatif Home Industri Desa Bodelor}

Berdasarkan hasil analisis yang didapat dari hasil observasi, wawancara, dokumentasi dan catatan di lapangan, secara garis besar produk usaha kreatif yang ada di desa Bodelor dibagi menjadi 3 (tiga), yaitu pertama, kerajinan rotan. Perabotan rotan memang masih menjadi primadona bagi para perajin di Indonesia, khususnya di desa Bodelor. Selain bahan bakunya yang mudah ditemukan, tekstur rotan tergolong fleksibel untuk dijadikan aneka kerajinan. Ada yang bisa diolah menjadi furniture murni, produk interior, dan bahkan aneka kreasi mini sekedar pemanis ruangan. Ditangan para perajin, rotan bisa menjadi bahan baku yang mudah diolah menjadi berbagai barang jadi untuk berbagai keperluan. ${ }^{45}$ Produk yang dihasilkan berupa, kuda-kudaan, ayunan bayi, kuda antik, kuda kepang, kursi kerang, kursi kecil, rak buku, sketsel, piring rotan, lampion dan kursi metik.

Kedua, kerai bambu. Kemampuan setiap pemilik home industri kerajinan bambu di desa Bodelor dalam mengembangkan usahanya berbeda-beda. Para pemilik home industri yang ada di desa Bodelor ini masih menggunakan tenaga manusia. ${ }^{46}$ Produk yang dihasilkan berupa, Seperti kerai kulit (diambil dari kulit luar bambu), dan kerai isi (diambil dari bagian dalam bambu). Bukan hanya kerai dari bahan bambu saja, di home industri ini terdapat juga kerai fiber dan kerai kayu.

Dan Ketiga, konveksi. Usaha konveksi yang ada di desa Bodelor merupakan jenis usaha yang banyak di geluti oleh masyarakat desa Bodelor karena hanya dengan bermodalkan kecil dapat

\section{${ }^{45}$ Iwan Sudayat, Sukses Membangun} Industri Kreatif (Yogyakarta: Smart Pustaka, 2015), 69.

${ }^{46}$ Hasil wawancara dengan Ibu Baeriyah, Pengusaha Kerajinan Rotan pada tanggal 11 Juli 2017. 
menjalankan usaha ini. Jenis usaha yang ada diantaranya kerudung dan mukenah.

\section{Relevansi Mekanisme Pasar Ibn Khaldun Dengan Home Industri di Desa Bodelor}

Terlihat dari pemikiran Ibn Khaldun sendiri mengenai teori harga, bahwa Ibn Khaldun membagi jenis barang menjadi barang kebutuhan pokok dan barang mewah. Menurutnya, apabila sebuah kota telah makmur dan berkembang dan selanjutnya populasi bertambah banyak, maka hargaharga kebutuhan pokok akan mendapat prioritas pengadaannya. ${ }^{47}$ Akibatnya penawaran meningkat dan ini berarti turunnya harga. Adapun untuk barangbarang mewah, permintaannya akan meningkat sejalan dengan berkembanganya kota dan berubahnya gaya hidup. Akibatnya harga barang mewah meningkat. ${ }^{48}$

Ibn Khaldun juga menegaskan mekanisme penawaran dan permintaan dalam menentukan harga keseimbangan. Naik turunnya penawaran terhadap harga ketika barang-barang yang tersedia sedikit, harga-harga akan naik. Namun bila jarak antar kota dekat dan aman untuk melakukan perjalanan, akan banyak barang yang diimpor sehingga ketersediaan barang akan melimpah dan harga-harga akan turun. Selain itu, Ibn Khaldun menambahkan faktor lain yang dapat mempengaruhi harga barang tersebut yaitu pajak. Sehingga pungutan dan pajak mempunyai peranan yang mampu menjadi pengatur stabilitas harga.

Dalam teori nilai, Ibnu Khaldun menitikberatkan tenaga kerja sebagai sumber yang berharga. Ibn Khaldun menganggap bahwa tanpa tenaga kerja keuntungan dari akumulasi modal dan pendapatan tidak dapat diraih. Ibnu Khaldun menekankan bahwa usaha dari para pekerja dalam sebuah proses pembuatan kerajinan

\footnotetext{
${ }^{47}$ Adiwarman A. Karim, Ekonomi Mikro Islami (Jakarta: RajaGrafindo Persada, 2008), 148. Islami, 148.
}

adalah suatu nilai yang berharga, bahkan nilai tersebut harus ditambahkan pula ke dalam biaya produksi karena tanpa buruh/pekerja kerajinan tersebut tak dapat diproduksi. Dengan kata lain, substansi nilai adalah kerja para buruh yang memiliki skill yang mampu memberikan sumber nilai dalam hasil produksi. ${ }^{49}$

Bagi Ibn Khaldun, intervensi negara terhadap mekanisme pasar hanyalah untuk meningkatkan efisiensi, bukan bentuk campur tangan secara murni. Ibn Khaldun berpendapat bahwa pemerintah tidak dapat ikut campur dalam mekanisme pasar. Sejatinya pemerintah hanya bersikap sebagai wasit atau pengadil dalam transaksi ekonomi masyarakatnya dan itu dapat dilihat dari diperlukannya lembaga hisbah yang bertugas untuk mengawasi keadaan dalam pasar sekaligus berhak menjatuhkan hukuman apabila ditengarai terjadi kecurangan di dalam pasar. ${ }^{50}$

Untuk mengimbangi pemikiran teori dari Ibn Khaldun tentang mekanisme pasar, peneliti akan mengkolerasikan dengan teori Monzer Khaf untuk membaca hasil studi yang ada di desa Bodelor. Teori Ibn khaldun ini diperkuat dengan teori dari Monzer Khaf, bahwa ekonomi Islam adalah ekonomi yang bebas, tetapi kebebasannya ditunjukan lebih banyak ke dalam kompetisi (persaingan). Memandang keadilan sebagai akibat dari aturan umum, yaitu penilainan yang tepat atas produksi, penetapan harga output yang tepat dan retribusi output (pendapatan) bagi mereka yang tidak mampu mendapatkan melalui kekuatan pasar, dalam hal ini melibatkan zakat. Sedangkan keterlibatan pemerintah dalam pasar hanyalah pada saat tertentu atau bersifat temporer. Ia dianggap sebagai

\footnotetext{
${ }^{49}$ Muslim, "Mekanisme Harga Menurut Pemikiran Ibnu Khaldun", dalam http://repository.uin-suska.ac.id/2010. Diakses pada tanggal 23 Oktober 2017.

${ }^{50}$ Nurul Huda, "Harga dan Mekanisme Pasar", dalam http://publikasiilmiah.ums.ac.id. Diakses pada tanggal 23 Oktober 2017.
} 
perencana, pengawas, produsen juga sebagai konsumen. ${ }^{51}$

Setelah melihat bagaimana penggambaran Ibn Khaldun yang diperkuat dengan teori dari Monzaer Khaf. Di sini yang menjadi dasar bagi peneliti dalam melihat realita yang ada di desa Bodelor ialah terletak pada konsep permintaan dan penawaran, juga produktifitas para pekerja. Di dalam beberapa home industri yang ada, seperti kerajinan rotan, kerai bambu dan usaha konveksi, konsep permintaan dan penawaran merupakan sebab akibat naikturunnya harga itu ketika dilihat dari proses produksinya.

Apabila suatu produk mengalami kenaikan harga, ini terjadi akibat bahan baku pembuatan produk tersebut mengalami kenaikan yang disebabkan adanya bea cukai (pajak) atas bahan baku produksi, karena diambil dari luar desa atau bahan baku produksinya tidak tersedia dipasaran sehingga tidak dapat memenuhi permintaan pasar. Dari kenaikan bahan baku pembuatan produk, diakibatkan juga menimbulkan kenaikan suatu barang yang diproduksi. Selain dari bahan bakunya, para perkerja juga dapat menyebabkan kenaikan harga. Jika pekerja tidak produktif lagi dalam membuat produk (saat libur) stok barang yang ada berkurang tetapi permintaan produk meningkat, maka akan menyebabkan kenaikan dalam produk.

Tetapi berbeda dalam hal penurunan harga karena hanya terjadi pada produk tertentu seperti kursi mio, dan usaha konveksi kerudung. Sedangkan di beberapa home industri yang lain jarang mengalami penurunan harga secara signifikan. Karena barang yang diproduksi merupakan produk yang tahan lama.

Sedangkan dalam hal pemerintah, yang dirasakan oleh ibu $\mathrm{Hj}$. Yama mengenai bentuk intervensi dari pemerintah, pemerintah tidak ikut andil dalam

\footnotetext{
${ }^{51}$ Joni Tamkin, "Metodologi Ekonomi Islam: Suatu Analisis Perbandingan", dalam http://ejournal.um.edu. Diakses pada tanggal 24 Juli 2017.
}

berjalannya mekanisme pasar. Menurutnya, home industri yang ada hanya berupa usaha kecil menengah sehingga tidak perlu adanya campur tangan pemerintah. ${ }^{52}$

Kesimpulannya, peneliti menemukan adanya kesamaan pemikiran Ibn Khaldun mengenai pemerintah dan realita di home industri yang ada di desa Bodelor. Pemerintah tidak ikut campur tangan dalam berjalannya mekanisme pasar, melainkan pemerintah hanya sebatas mengawasi jalannya mekanisme dalam pasar. Jika ada suatu pelanggaran, maka pemerintah akan bertindak sebagai penegak yang adil.

Sedangkan dari teori harga, teori nilai dan pemerintah. Terdapat kesamaan dalam proses terjadinya kenaikan harga suatu barang yang diakibatkan adanya permintaan dan penawaran salah satunya karena bea cukai yang ada dalam bahan baku produksi. Dengan kata lain, pemilik home industri (produsen) mengalihkan beban pajak tadi kepada konsumen melalui harga jual produk yang lebih tinggi. Serta dari upah para pekerja yang merupakan sesuatu yang berharga dalam menentukan sumber nilai dalam hasil produksi.

Tetapi perbedaannya ialah dalam hal penurunan harga dari beberapa home industri yang ada seperti kerajinan rotan, kerai bambu dan mukenah jarang terjadi penurunan harga. Dari sisi pembuatan produknya juga merupakan barang yang tahan lama yang dapat dipakai dalam jangka waktu panjang. Kebutuhan akan produk tersebut juga relatif stabil dari segi permintaan dan penawarannya, sehingga jarang terjadi penumpukan barang, Jika terjadi penumpukan barang juga dapat dijual kembali dengan harga yang sama dan tidak mengalami penurunan harga, karena permintaan akan produk tersebut tidak pernah mati di pasaran. Berbeda dengan apa yang dikemukakan oleh Ibn Khaldun tentang teori permintaan dan penawaran

${ }^{52}$ Hasil wawancara dengan ibu $\mathrm{Hj}$. Yama, Pemilik Usaha Konveksi Kerudung pada tanggal 26 Februari 2017. 
dalam harga bahan pokok makanan yang dibutuhkan oleh manusia setiap harinya, sehingga jika terjadi penumpukan barang akan dijual dengan harga murah. Dalam hal ini, naik turunnya harga lebih sering disebabkan oleh adanya permintaan dan penawaran.

Peneliti akan mengilustrsikan kenaikan harga dan keseimbangan harga terhadap permintaan dan penawaran, sesuai dengan keadaan home industri yang ada.

\section{Harga Produk dalam Permintaan dan Penawaran}

\begin{tabular}{|c|c|c|c|}
\hline No & Produk & Harga & Keterangan \\
\hline \multirow[t]{3}{*}{1.} & $\begin{array}{l}\text { Kerajinan } \\
\text { Rotan }\end{array}$ & Stabil & $\begin{array}{l}\text { Penawaran } \\
\text { masih bisa } \\
\text { memenuhi } \\
\text { permintaan } \\
\text { pasar. }\end{array}$ \\
\hline & & Naik & $\begin{array}{l}\text { Pasokan bahan } \\
\text { baku } \\
\text { berkurang. }\end{array}$ \\
\hline & & Turun & \begin{tabular}{ll}
\multicolumn{2}{l}{ Banyaknya } \\
pesaing yang \\
membuat jenis \\
produk yang \\
sama.
\end{tabular} \\
\hline \multirow[t]{3}{*}{2.} & $\begin{array}{l}\text { Kerai } \\
\text { Bambu }\end{array}$ & Stabil & $\begin{array}{l}\text { Penawaran } \\
\text { masih bisa } \\
\text { memenuhi } \\
\text { permintaan } \\
\text { pasar. }\end{array}$ \\
\hline & & Naik & $\begin{array}{l}\text { Pasokan } \\
\text { barang } \\
\text { berkurang } \\
\text { sedangkan } \\
\text { para pekerja } \\
\text { tidak dapat } \\
\text { memenuhi } \\
\text { permintaan } \\
\text { pasar. }\end{array}$ \\
\hline & & Turun & $\begin{array}{l}\text { Kerai bambu } \\
\text { tidak pernah } \\
\text { mengalami } \\
\text { penurunan } \\
\text { harga karena }\end{array}$ \\
\hline
\end{tabular}

\begin{tabular}{|c|c|c|}
\hline & & $\begin{array}{l}\text { permintaan } \\
\text { dan penawaran } \\
\text { cenderung } \\
\text { stabil. }\end{array}$ \\
\hline \multirow[t]{3}{*}{ 3. $\quad$ Kerudung } & Stabil & $\begin{array}{l}\text { Penawaran } \\
\text { masih bisa } \\
\text { memenuhi } \\
\text { permintaan } \\
\text { pasar. }\end{array}$ \\
\hline & Naik & $\begin{array}{l}\text { Permintaan } \\
\text { tinggi dan } \\
\text { bahan baku } \\
\text { untuk produksi } \\
\text { mengalami } \\
\text { kenaikan. }\end{array}$ \\
\hline & Turun & $\begin{array}{l}\text { Ketinggalan } \\
\text { model. } \\
\text { Penjualan } \\
\text { melakukan } \\
\text { pengobralan } \\
\text { barang. }\end{array}$ \\
\hline \multirow[t]{3}{*}{ 4. Mukenah } & Stabil & $\begin{array}{l}\text { Penawaran } \\
\text { masih bisa } \\
\text { memenuhi } \\
\text { permintaan } \\
\text { pasar. }\end{array}$ \\
\hline & Naik & $\begin{array}{l}\text { Permintaan } \\
\text { tinggi dan } \\
\text { bahan baku } \\
\text { untuk produksi } \\
\text { mengalami } \\
\text { kenaikan. }\end{array}$ \\
\hline & Turun & $\begin{array}{l}\text { Mukenah } \\
\text { cenderung } \\
\text { tidak pernah } \\
\text { mengalami } \\
\text { penurunan } \\
\text { harga. }\end{array}$ \\
\hline
\end{tabular}

\section{KESIMPULAN}

Berdasarkan hasil penelitian di atas, dapat disimpulkan 3 (tiga) macam, pertama mekanisme pasar menurut Ibn Khaldun ialah sebuah sistem yang menentukan terbentuknya harga, di mana ditentukan oleh adanya hukum permintaan dan penawaran, distribusi, kebijakan pemerintah, pekerja, uang, pajak dan keamanan. Menurut Ibn 
Khaldun di dalam prosesnya mekanisme pasar diharuskan adanya asas moralitas, persaingan yang sehat, kejujuran, keterbukaan dan keadilan. Jika nilai-nilai ini telah ditegakkan, maka tidak ada alasan untuk menolak harga pasar.

Kedua, produk usaha kreatif home industri yang ada di desa Bodelor memiliki berbagai macam jenis produk usaha diantaranya seperti kerajinan rotan produknya berupa kuda-kudan, lampu brekele, piring rotan, kursi mio, lampu duduk. Kerai bambu, jenis produknya berupa kerai isi, kerai kayu, kerai kulit, kerai sintesis. Kerudung dan mukenah.

Dan ketiga, relevansi dari pemikiran Ibn Khaldun mengenai mekanisme pasar dengan home industri yang ada di desa Bodelor ini, dalam menentukan terbentuknya suatu harga dilihat dari permintaan dan penawaran, upah para pekerja, pajak dan pemerintah sebagai lembaga yang mengawasi berjalannya mekanisme pasar. Terdapat kesamaan dalam proses terjadinya kenaikan harga suatu produk, namun perbedaannya dari segi penurunan harga.

\section{DAFTAR PUSTAKA}

Abdullah, Boedi dan Beni Ahmad Saebani. Metode Penelitian Ekonomi Islam (Muamalah). Bandung: Pustaka Setia, 2014.

Al-Kaaf, Abdullah Zakiy. Ekonomi dalam Perspektif Islam. Bandung: Pustaka Setia, 2002.

Al-Qur'an Al-Hidayah, Tafsir Perkata Tajwid Kode Angka. Tanggerang: Kalim, 2010.

Amalia, Euis. Keadilan Distributif dalam Ekonomi Islam. Jakarta: Rajawali Pers, 2009.

Amalia, Euis. Sejarah Pemikiran Ekonomi Islam. Depok: Gramata Publishing, 2010.

Arifin, M. "Studi Komparatif tentang Mekanisme Pasar Ibnu Khaldun dan Adam Smith", dalam http://digilib.uinsby.ac.id/1981/.
Diakses pada tanggal 23 Oktober 2017.

Arikunto, Suharmi. Management Penelitian. Jakarta: Rineka Cipta, 1993.

Askandar, Noor Shodiq. 99 Great Ways Menjadi Pengusaha Muslim Sukses. Jakarta: Erlangga, 2013.

Boone, Louis E. Pengantar Bisnis Kontemporer. Jakarta: Salemba Empat, 2013.

Deddy, Mulyana. Metodologi Penelitian Kualitatif. Bandung: Remaja Rosdakarya, 2011.

Hairuddin, Enni K. Kreatif Mencipta Produk. Jakarta: Progressio, 2016.

http://kbbi.web.id/usaha. Diakses pada tanggal 17 Mei 2017.

Huda, Choirul. "Pemikiran Ekonomi Bapak Ekonomi Islam Ibnu Khaldun", dalam

http://journal.walisongo.ac.id.

Diakses pada tanggal 27 Februari 2017.

Huda, Nurul. "Harga dan Mekanisme Pasar", dalam http://publikasiilmiah.ums.ac.id.

Diakses pada tanggal 23 Oktober 2017.

Jaelani, Aan. "Hisbah and Market Mechanism: The Morality Study of Market Participants in Islamic Economic Perspectiv", dalam https://mpra.ub.unimuenchen.de/69526/. Diakses pada tanggal 02 Maret 2017.

Karim, Adiwarman A. Ekonomi Mikro Islami. Jakarta: PT RajaGrafindo Persada, 2008.

Mastuti, Indari dan Agustin Rozalena. Mencicipi Kesuksesan Amanda Brownis Kukus. Bandung: Kaifa, 2010.

Moeloeng, Lexy J. Metodologi Penelitian Kualitatif. Bandung: Remadja Karya, 1986.

Furqon, Muhammad. "Pemikiran Ekonomi Ibn Khaldun dalam Mekanisme Pasar", dalam http://eprints.ums.ac.id/30877/. 
Diakses pada tanggal 23 Oktober 2017.

Muslim. "Mekanisme Harga Menurut Pemikiran Ibnu Khaldun", dalam http://repository.uinsuska.ac.id/2010. Diakses pada tanggal 23 Oktober 2017.

Nelistya, Linda. "Pasar Monopolistik", dalam http://www.academia.edu. Diakses pada tanggal 22 Maret 2017.

Nophirin. Pengantar Ekonomi Makro. Yogyakarta: BPEE, 2012.

R., Lerbin dan Ariotang R. Riset Pemasaran. Jakarta: Ghalia Indonesia, 2007.

Saiman, Leonardus. Kewirausahaan Teori, Praktik dan Kasus-kasus. Jakarta: Salemba Empat, 2009.

Santoso, Teguh. Marketing Strategic. Yogyakarta: Oryza, 2011.

Sudayat, Iwan. Sukses Membangun Industri Kreatif. Yogyakarta: Smart Pustaka, 2015.

Suhaimi, "Pemikiran Ibnu Khaldun tentang Perdagangan, Rasio Keuntungan dan Mekanisme Pengawasan Pasar dalam Kitab Al-Muqaddimah”, dalam http://respository.uinsuska.ac.id. Diakses pada tanggal 15 Juni 2017.

Suryabrata, Sumardi. Metedologi Penelitian. Jakarta: Raja Grafindo, 2004.

Susana, Siti. "Peran Home Industri dalam Meningkatkan Kesejahteraan Masyarakat Menurut Perspektif Ekonomi Islam", dalam https://repository.uin-suska.ac.id.

Diakses pada tanggal 04 Maret 2017.

Susanto, A. B. Susanto, Management For Everyone 5 Human Capital. Jakarta: Erlangga, 2011.

Tamkin, Joni. "Metodologi Ekonomi Islam: Suatu Analisis Perbandingan", dalam http://e-journal.um.edu. Diakses pada tanggal 24 Juli 2017.

Udin, Asep. "Teori Permintaan dan Penawaran Ibnu Khaldun", dalam www.academia.edu. Diakses pada tanggal 09 April 2017.

Ulya, Husna N. "Permintaan, Penawaran dan Harga Perspektif Ibnu Khaldun", dalam http://jurnal.stainponogoro.ac.id. Diakses pada tanggal 05 April 2017.

Winardi, Jozef. Peran Usahawan dalam Pembangunan Indonesia. Bandung: Tarsito, 1977.

Zuliati, et.al. "Pengembangan Wirausaha Industri Kreatif Melalui Inovasi Produk Berbasis Syariah", dalam http://dppm.uii.ac.id/. Diakses pada tanggal 02 Maret 2017. 